\title{
Commodification of the Qur'an in Brand Marketing Community of Dinar Khoirur Roziqin Indonesia
}

\author{
Ahmad Fawaid ${ }^{1, *}$ Nafi'ah Mardlatillah $^{2}$ \\ ${ }^{1}$ Nurul Jadid University, Probolinggo, Indonesia \\ ${ }^{2}$ Nurul Jadid University, Probolinggo, Indonesia \\ *Corresponding author. Email: ahmadfawaidfuady@gmail.com
}

\begin{abstract}
This article aims to figure out the commodification of the Qur'an in the marketing brand of Dinar Khoirur Rooziqiin (Dinar KR). As a new product in the gold business sector, Dinar KR has won a place in the people's hearts. Its community extends to various regions in Indonesia and even neighbouring countries. Dinar KR exploits the Qur'an as a marketing strategy by using Qur'anic verse numbers in their promotional pictures and pamphlets on Instagram, Facebook, website, and Telegram. Religious activities such as khatm al-Qur'an are also encouraged in their communities as religious gatherings and marketing media. By using descriptive analysis and the theory of commodification of religion, this study concludes that the practice of using the Qur'an as a marketing brand for Dinar KR has met two indicators of commodification, namely commodities and markets. In this case, the commodity in question is a gold coin filled with verses from the Qur'an. By using descriptive analysis and the theory of commodification of religion, this research produces two findings; first, using verses of the Qur'an as a product marketing practice can increase high selling power. It is due to the dominance of the Pop Religious lifestyle of the Indonesian people. Second, there is an ideological infiltration of Post-Islamism in the Dinar Khairur Rozikin community leading to the unity of Islamic Politics.
\end{abstract}

Keywords: Commodification, Brand Marketing, Dinar Khoirur Rooziqiin.

\section{INTRODUCTION}

As a transaction tool at the Prophet's time, the Dinar is currently a new trend for the religious community in Indonesia. This transaction began with news of the muamalah market in the Beji area, Depok, which made transactions with Dinar and Dirham. The market, which operates without a permit from the local authorities, immediately received a warning from the government. Through BI, the government emphasized that the only transaction tool that can use in Indonesia is Rupiah[1].

Not long after the news circulated, on February 2, 2021, the Criminal Investigation Police arrested a muamalah market salesperson, Zaim Saidi, for violating Law no. 7 of 2011 on the currency. The perpetrators are threatened with a maximum sentence of one year and a maximum fine of 200 million Rupiah [2]. Based on the framing analysis of several mainstream media reporting on the case, there are indications that the government seems traumatized by indications of the application of Islamic law that led to the Khilafah system, including the use of Dinar in transactions [3].

In this context, a company produces Dinar with several verses of the Koran on each chip, namely Dinar Khoirur Rooziqiin. They claim that the printed Dinar is only a commodity, not a currency exchange. The design of this Dinar piece contains an excerpt from the Qur'anic verse, namely the prayer of the Prophet Moses, which reads: "warzuqnaa wa anta khoirur rooziqiin" [4] (the excellence of dinar khoirur rooziqiin). In addition, the symbols printed on each chip also refer to the Qur'an a lot, such as the image of rice, which they think symbolizes prosperity, as stated in the QS. al-Nūr: 55 and QS. al-Anbiyā': 105. Also, the year of publication using hijriyah, namely 1441 , is associated with prayer in the 14th chapter, verse 41 . The number 1441 is also used as an acronym for "one hundred Dinars for every Muslim for preparation one imam," an ideological slogan massively narrated to their community [4].

It is undeniable, for Muslims, the position of the Qur'an is not only a guide but also the Qur'an is often used in human life, politically, economically, and 
socially. In the study of the Qur'an, the socio-political phenomenon that positions the Qur'an as an inspiration is typified as a study of the Living Qur'an. The phenomenon of Dinar Khoirur Rooziqiin is interesting to study from the perspective of the living al-Qur'an. That is because this community not only emphasizes business activities but also has an ideological dimension and a marketing system that utilizes the verses of the Qur'an to attract buyers.

There are not many studies that discuss Dinar Khoirur Rooziqiin, especially in commodifying the Qur'an as marketing. One of the studies the author found about the Dinar was Zaenal Masduqi, but this paper focuses on investigating the history of the Dinar in Indonesia. Zaenal analyzes the Dinar genealogically, which was used as a transaction in Indonesia by Arab traders [5]. This research has nothing to do with the discussion of the reception and commodification of the verses of the Qur'an printed on the Dinar.

This study takes another perspective from the above research by looking at the portrait of the commodification of the Koran in the Dinar Khoirur Rooziqiin community and how the reception of members of the Dinar Khoirur Rooziqiin community towards the verses used as Brand Marketing. This study also seeks to reveal the practice of using verses of the Qur'an as promotion on social media and private groups, both clear verses in each chip and verses implied in symbols. This research will have novelty value, not only because it is not published about this, but because the Qur'an is perceived as a commodification tool and a symbol of brand marketing.

\section{QURANIC MARKETING MINIGOLD AND DINAR KHOIRUR ROZIQIIN}

Dinar Khoirur Rooziqiin (next, Dinar KR) is relatively new in Indonesia than Antam's Dinar and several other brands. PT DKRI produces the KR Dinar with an office based in Depok, West Java. Even though it was launched on July 28, 2020, the Dinar KR community is overgrowing, with the current number of members reaching 142,002 people, Official Representatives 402 people, and Partners as many as 3,276 people (community).

The rapid development of the KR Dinar is based on many competitiveness that the KR Dinar offers to consumers. First, they claim that the KR Dinar contains blessings so that whoever has it first will get fluency in all affairs of life. Second, the KR Dinar appears during a large community, and its members have spread to various parts of Indonesia and even to neighboring countries, namely the Magnet Rejeki (MR) community. With this, it is not difficult to attract members of the MR community to become Dinar KR partners, Third, the KR Dinar uses many Islamic instruments, taking advantage of Indonesia's substantial spiritual market potential. In addition to using several verses of the Qur'an, they also collaborated with several religious figures who were familiar with people's lives, such as Habīb Muhammad Luṭi bin Yahyā [6], Tengku Zulkarnain[7], and Syekh Ali Jaber [8].

With the vision "to become a leading provider of gold, Dinar and Islamic jewelry in Indonesia," Dinar KR provides five variants of Dinar products. Two of them are special editions, namely a quarter of the Dinar of Masjid al-Aqșa and a quarter of the Dinar of Aya Sofia. The other three are half Dinars of the Prophet's Mosque, one Dinar of Masjid al-Haram, and two Dinars engraved remembrance of the kiswah of the Kaaba. Nasrullah leads the Dinar KR printing company as founder and primary director, Abus al Halimi as Executive Director, and Ettie Nurhayati as Finance Director [4].

Before deciding to produce Dinar KR, the founder of PT, DKRI, has already built a community whose material can be accessed by anyone via Telegram and Youtube, namely the Magnet Sustenance community. This community, which is engaged in the socioreligious field, has a movement focus on the Magnet Sustenance Science training [9] through the application of sustenance magnetism, this community is expanding, not only in the economic area but also in the fields of education and health. Therefore, the number of training members is increasing day by day [9]. It is made Dinar KR not encounter any significant problems during the marketing process. The number of subscribers to this community's Telegram channel has reached 130 thousand people. Meanwhile, the Magnet Sustenance channel built on YouTube has won the Silver Play Button award [10].

Currently, Dinar KR already has a large community spread across several cities, such as Surabaya, Banten, Padang, Makassar, Pati, Pekanbaru, Bandung, and even Malaysia. In addition, they also built small communities in many other cities. Communication is carried out through several conferences on land and social media platforms such as Facebook, Whatsapp, and Instagram (community).

In the Dinar KR community, everyone who becomes a first-hand partner has a direct affiliation with the center, and they are called WR (Official Representative). A WR is given the authority to recruit as many subordinates as possible, and these subordinates are referred to as PDKR (Dinar KR Fighters) or MDKR (Mitra Dinar KR). One of the methods used by WR to look for PDKR is by placing attractive promotions on media platforms such as Facebook and then providing a link to a more private group on Whatsapp. After entering the Whatsapp group, the PDKR candidate is given some persuasive material hoping that the candidate will be interested and register to become PDKR [11]. 
If we pay attention to the product design, Dinar KR has an implied mission to re-establish the Khilafah system of government. This proof is contained in the printed number 1441, which describes the Hijri year when the coins were minted and an acronym for one hundred dinars 4 every Muslim for preparation one imam. In addition, when price updates are sent to social media, they provoke that the Dinar was victorious during the Prophet's time and will be victorious again at the end of time. Likewise, the mindset that is firmly embedded in the official website, that the KR Dinar community is a historical connector for the broken glory of Islam. In the future, the next generation will genuinely enjoy the glory of Islam with gold coins, they said [4].

Dinar KR's marketing technique is to take advantage of the condition of Indonesia, which is the largest Muslim country in the world. Dinar KR uses a lot of the Qur'an in its promotional tools. Verses of the Qur'an can be easily found on the official website, promotional materials, official social media accounts, as well as social media accounts belonging to the WR and PDKR networks.

In general, the central management of Dinar KR is to form a community environment for al-Qur'an lovers. They encourage partners and consumers of Dinar KR to interact with the Qur'an in three ways. First, interact with the Qur'an as contained in the symbol of each KR Dinar. Second, they insert several verses of the Qur'an on the official website as well as pamphlets of promotional materials. Furthermore, thirdly, every Friday, they encourage partners to read surah al-Kahf and pray in QS. Al-Māidah: 114 became the primary reference and basis for taking the name Dinar KR.

\section{BRAND MARKETING PRACTICES; RECEPTION OF THE USE OF VERSES ON DINAR KR PRODUCTS}

As explained earlier, the promotion technique for the KR Dinar is to use verses from the Koran and religious symbols. In most, the verses used in the KR Dinar community are motivational or prayer verses. It is because the Qur'an does not explain in detail about gold, investment, or savings. The KR Dinar community uses hadith more to be used as a specific argument for the primacy of gold.

As explained earlier, the promotion technique for the KR Dinar is to use verses from the Koran and religious symbols. In most, the verses used in the KR Dinar community are motivational or prayer verses. It is because the Qur'an does not explain in detail about gold, investment, or savings. The KR Dinar community uses hadith more to be used as a specific argument for the primacy of gold. The following are details of the practice of using the Qur'an as a marketing brand in several Dinar Khoirur Rooziqiin media:

\subsection{Instagram}

In Dinar KR's official Instagram account, there are two receptions: Exegesis/Hermeneutical and Aesthetic receptions. Both types of receptions are contained in promotional content in pamphlets accompanied by captions. If observed thoroughly, all the verses of the Qur'an that were responded to hermeneutically in Dinar KR's Instagram account are motivational, prayers, and commemorations of several Islamic holidays. There is absolutely no verse about saving, investing, or gold (Dinar). It is understandable because the Qur'an never directly mentions gold, much less investment or savings. Therefore, the KR Dinar uses the hadith more to explain the virtues of the Dinar, specifically.

Here are some verses that were exegesis received on Dinar KR's official Instagram account. The first verse seen on this Instagram account feed is QS. alInshirah. This verse is equipped with a translation, pictures of the Qur'an and lanterns, as well as a caption which is essentially a motivation for the reader. Everyone must have problems, and Allah promises to provide a way out for His servants. In this pamphlet, verses 5-7 are listed. However, the caption only explained verses 5 and 6 , so the reader could not understand the meaning of verse 7 in this pamphlet.

In addition, the verse used in Instagram is also QS. Al-A'raf: 23. The verse contained the prayer of the Prophet Adam when he asked for forgiveness, accompanied by a motivational caption. They also urge that anyone who sins still has the opportunity to return to the right path by repenting. However, in the next slide, they also threaten that anyone who commits a sin and despairs Allah's mercy will become a follower of the devil [12].

Another verse is QS. Al-Baqarah: 201. In the Instagram caption column, they explain that this verse is one of the favorite prayers of the Prophet Muhammad. There is also an invitation always to include this prayer in every prayer said [12]. The three verses are written in total, starting from pronunciation and translation, accompanied by captions and illustrations. While the following two verses, QS. AlBaqarah: 158 and al-Haj: 37, which commemorate important Islamic days, Ramadan and Eid al-Adha, are only written in the form of translations, captions, and pictures.

Furthermore, three verses are only written in translation, accompanied by pictures and captions. First is QS. al-Hujurat: 10. The explanation of the translation of this verse is interrupted by the sentence after it because they only include the translation of the fa aslihū text. At the same time, the snippet of the previous paragraph is not included. This verse invites readers to forgive each other and maintain brotherhood. According to them, the brotherhood of fellow believers is stronger than the kinship brotherhood. Although it does not include references, this statement aligns with 
al-Șabūnī's interpretation of this verse. In his book, alSabuni explains brotherhood because lineage is meaningless without ukhuwah Islamiyah [13].

The second verse is QS. Al-Talaq: 2-3. The written caption shows that this verse is used to commemorate Friday and always fix worship. The translation of these two verses is also not entirely written. The pamphlet only includes the end of verse 2 and the beginning of verse 3 . The truncation of this verse is the same as that of Ibn Kathir in his book [14]. However, the caption that accompanies this verse is inappropriate because most commentators explain this verse in the context of a solution to a problem, not about the motivation of worship to improve oneself [14]. The last verse is QS. Al-Maidah: 2. This verse also explains helping. In addition, the caption column was added to the suggestion to give alms to fellow Muslims as a commemoration of Friday.

From all the verses that were received exegesis in Dinar KR's official Instagram account, it can be concluded that these verses are only interpreted briefly using a few words but which describe the primary meaning of the verse. In that content, there is not a single reference in the form of books of interpretation of mu'tabarah, even though some of the interpretations are similar to one of the commentaries. Most verses do not include the pronunciation, but only in a translation.

In addition to the verse that was received exegesis, the Dinar KR Instagram account also contained an explanation in the form of an infographic about the meaning of the engraving on the Dinar KR chip. This engraving uses several verses of the al-Qur'an either by writing the verse directly or absorbing the meaning and then representing it with an object. The use of this verse as an engraving is included in aesthetic reception. The verse that is carved directly and is the most crucial verse in the KR Dinar community is the final cut of the QS. Al-Maidah: 114. This prayer of Prophet Isa is always chanted and even engraved on each piece, hoping that there will be a miracle from Allah. In addition, they also hope to be able to gift this Dinar to Prophet Isa at the end of time [15].

Another verse on the KR Dinar engraving is visualized as an object. The first is rice. They consider rice a symbol of prosperity, God's promise to Muslims at the end of time, which is extracted from the QS. AlNür: 55 and QS. Al-Anbiya': 105. The last verse is represented in the form of numbers, namely the number 1441. Apart from being an indication of when the KR Dinar was issued in the Hijri calendar year, this number is also called the embodiment of the prayer that is in the 14th chapter (Ibrahim) verse 41[15].

\subsection{Facebook}

Another platform that Dinar $\mathrm{KR}$ uses as a promotional medium is Facebook. There are several verses in the official Dinar KR account as well as the accounts of partners that are received exegesis, aesthetically and functionally. The first verse is QS. AlMaidah: 114. The writing of this verse is complete with lafaz and its translation, but no caption describes how the person who uploaded it understands. However, it can be understood that the pamphlet containing this verse is an affirmation of the name Dinar KR as well as a prayer that they believe will facilitate their sustenance.

Another verse that is also received exegesis is the QS. Saba': 24. This verse is not written in pronunciation but only in translation. Mitra Dinar KR, who uploaded this verse, gave a caption in the form of a prayer to be given abundant sustenance by Allah SWT, according to the meaning of this verse. Furthermore, it is also found the use of QS. Fātị: 29-30. This verse is not written either lafaz or translation. The uploader only wrote his understanding of this verse. He said that this verse is a guide from Allah for anyone who wants to succeed in business. He then summarizes the instructions in this verse into five steps to a successful business, namely: interacting with the Qur'an, establishing prayers, increasing alms, starting a business, and the last is waiting for sustenance from Allah SWT (tawakkal) [16].

In addition to the three verses that were received exegesis, a form of aesthetic reception was also found in the account of one of Dinar KR's partners by using the al-Qur'an as a product photo base. In this picture, there is a miniature of the Kaaba, a flower pot, then the opened al-Qur'an to be used as a product photo base. It is not known for sure in what surah and verse because it can be understood that the uploader only wants to include aesthetics in the mushaf to beautify his product photos. He uses the al-Qur'an manuscripts that are familiar in Muslim life to attract the interest of the Indonesian people, who are predominantly Muslim.

Furthermore, there is also an available reception in the Dinar KR community every Friday. This activity has been carried out since March 20, 2020, and is led by the founder of Dinar KR through the live streaming of the official Dinar KR Facebook group. It is recorded that there are approximately 4,100 people who take part in this activity every week. Moments before the reading of al-Kahf began, a live streaming link was shared via the Dinar KR telegram channel. While waiting for the participants to attend, a question and answer session was held, PT carried out new product introductions and notifications about several social activities. DKRI, such as sending several volunteers to disaster-affected areas. This activity lasts approximately 90 minutes [17].

If we look closely, the reading of al-Kahf has three purposes. The first is to establish close relationships between partners and the leadership of the Dinar KR company, the second is to strengthen the unity of the Dinar KR community, and the last is to notify the 
company's latest developments, such as the existence of several new activities and products [17].

\subsection{Website}

Only one verse was found on the Dinar KR website, namely QS. Al-Qașaș: 57. This verse is written in full along with the pronunciation and translation in the story of the origin of the KR Dinar. The founder of Dinar KR responds to this verse exegesis and functionally. He explained that this verse was what he always read to convince himself until the KR Dinar was finally officially launched [4].

\subsection{Telegram}

Dinar KR melalui platform Telegram mencantumkan beberapa ayat yang diresepsi secara eksegesis dan fungsional. Jika diperhatikan secara menyeluruh, ayat-ayat yang diresepsi secara eksegesis pasti menjelaskan tentang motivasi menabung dan tipstips untuk melancarkan rezeki. Sedangkan semua ayat yang diresepsi secara fungsional digunakan untuk meneguhkan keyakinan dan mencari jalan untuk mendaftar menjadi bagian dari komunitas Dinar KR.

The first verse that is perceived as exegesis is QS. al-Nisa ': 9. This verse is interpreted as a motivation to save so that children and grandchildren will not be left in a weak (poor) condition later. Before this verse is included and its interpretation, there are several other explanations about the importance of having sufficient wealth. Saving for posterity then becomes a part of it. This verse was not written but only translated [18].

Next, there is QS. Al-Anfāl: 60. This verse also accompanies an explanation of the importance of wealth. It is explained that wealth is essential to fight in the way of Allah, as the content of this verse. This verse is not spelled out, but only a part of the translation is written [19].

Another verse found on the Telegram channel of one of the Official Representatives of the KR Dinar is QS. Nh: 10-12. This verse was written to explain the smooth running of sustenance through istighfar to Allah. According to the content of these three verses, it is explained that sin is very likely to be an obstacle to sustenance, and asking Allah for forgiveness can be the solution. In line with the previous two verses, these verses are not spelled out but only translated [20].

In addition, in the same channel found another verse, namely QS. al-Ra'du: 11. This verse emphasizes that the mind is influential in determining success and sustenance. Before this verse, a Qudsi hadith about Allah is also included, following the prejudices of His servants. In contrast to the previous few verses, this verse is written in full text and translation [21].

Next, found QS. Al-Talaq: 2-3 in the same channel. There is a discrepancy between the use of this verse and the explanation described above. This verse explains piety, while the previous explanation is about the virtue of tawadhu' to get the glory.

Turning to the functionally received verses, several Dinar KR telegram channels found three verses that experienced functional reception. All three are in a similar story, namely a story about a person's initial struggle to become a partner of Dinar KR. These three verses are not understood in-depth but are used as personal dhikr continuously until Allah grants their request to become Official Representatives of the KR Dinar. These three verses are QS. Ali Imran: 75, QS. Al-Tawbah: 41 and QS. Ghāfir: 55.

\section{CONSTRUCTION OF KR DINAR MEMBERS' IDENTITY THROUGH THE MAGNET REZEKI COMMUNITY AND DKR CLUB}

A special community is one of the other facilities that Dinar KR offers to its customers. They claim that Dinar KR is supported by one of the largest training communities in Indonesia, the Magnet Sustenance Community (MR). This community consists of people from all region levels in Indonesia and even abroad. Although not all members of the MR community are part of the KR Dinar, all elements of the KR Dinar use several 'concepts' taught in the MR community [4].

One of several MR concepts used by most Dinar KR members is the Tuning Fork. All members of the Dinar KR community are taught this concept through the Telegram Audio Magnet Rezeki channel. This Telegram channel is even open to the public, unlike some other company's internal channels regulated by privacy.

Through the audio on the MR channel, it was explained that the tuning fork concept is a method of solving problems with the Qur'an. The procedure is to perform ablution first, then pray any sunnah. Next, the perpetrator prayed fervently and then opened the Qur'an. The first verse that is seen is the verse that is believed to be a guide, a way out of whatever problem is being faced. One verse is then contemplated on its meaning and made into remembrance until the heart feels calmer and the solution to the problem experienced is finally found. There is a rule that the alQur'an used must be the al-Qur'an without a translation, because the person who practices this concept must contemplate the verse with his own heart and mind [16].

The Garpu Tala concept later became the hallmark of the Dinar KR community members. Almost all members of the Dinar KR community, from consumers, partners, official representatives, even to the central board and founder, practice this concept every time they face a problem. It can be seen from the contents of the KR Dinar Copy Writing Channel, most of which are testimonials on the Garpu Tala concept to expedite the affairs or transactions of the KR Dinar. The 
following is an example of a testimonial for using the Garpu Tala concept [17]:

Terus terang aku gak pernah tahu, juga gak mengikuti informasi2 ttg koin Dinar, dan juga ga berusaha cari tahu karena ga ada duit...gak kepikir deh...bisa ikutan mikir "emas", buat makan saja welleeh.....Alhamdulillah sudah bersyukur.

Tapi tadi terbaca chat Pak Nas di group WA. Keuntungan bila kita menjadi Wakil Resmi Dinar Khoirur Rooziqiin (WR DKR). Dan diharapkan teman2 utk sgera mendaftarkan diri. Tiba-tiba ada rasa ingiiiin banget ikut jadi WR DKR tapi gak faham. Lalu aku chat Pak Muhni minta dijelaskan. Ternyata bagus banget dan murah banget, sayang kalo ga ikut. Tapi ga pegang duit, dapat dari mana uang buat daftar WR DKR?

Aku langsung GARPU TALA. Dapat QS. Ghāfir ayat 53,54,55. Kata Pak Muhni dzikirkan ayat 55...

So be patient, Prophet, for what God has promised is sure to come. Ask forgiveness for your sins; praise your Lord morning and evening. (QS. Ghäfir: 55)

Coach Muhni Said: "Mak jleb ayat 55, zikirkan. makin banyak makin bagus. semoga datang keajaiban, zikirkan satu ayat full, baca artinya, ambil jadi petunjuk. Ikuti tuntunannya, taati perintahnya, getarkan jiwa kita hingga Allah turunkan ketenangan dan beri solusi terindah." Siap laksanakan.!!

Abis dzikir pergi main ke tempat bibi (73 th, adek ayah). Ngobrol ngalor ngidul ttg Corona, sampai obrolan tentang saran ulama buat nyimpan emas. Lalu spontan aku buka video yang dikirim pak Muhni tentang saran menyimpan emas oleh ust. Haikal Hasan...ternyata adalah ust. favoritnya bibiku, sekalian aku cerita ttg WR DKR. Tibatiba..ujug-ujug...mak bedunduk...sudenlly... bibi masuk kamar lalu keluar lagi bawa beberapa juta uang (ternyata jumlahnya sama dengan jumlah yang dibutuhkan untuk mendaftar WR DKR).

Kaget ketika ternyata uang tersebut disodorkan kepadaku dan beliau bilang, "Daftar gih sana. Bibi mau bela ummat". Masya Allah, tabarakallah, alhamdulillah. Saya sudah daftar WR DKR, Allah Maha Baik, aku makin yakin Al Qur'an adalah sebaik-baik Solusi.

The narration above illustrates that the tuning fork concept initially only used in the Magnet Rezeki community is also very familiar in various KR Dinar transactions. Even if someone is only a partner of Dinar KR and was not previously a member of the MR community, he or she must also be familiar with and almost certainly practice the tuning fork concept. Through many similar stories above, the central leadership of Dinar KR instilled the doctrine that the Tala Fork concept is the hallmark of the MR and Dinar KR communities. They claim that the tuning fork concept is the best solution technique because people who use it will always surrender and return to the alQur'an.

In addition to the statement above, there is also a testimony from one of the Official Representatives of Dinar KR, who has had a smooth business from the first time he registered until the sales process for making QS. Ali Imran: 75 as a remembrance. He also got this verse from the tuning fork method.

Saat saya pertama sekali ingin jadi Wakil Resmi, jujur saya gak pede. "Mosok iya sih gak punya modal pengen bisnis emas, gak nyadar kali ya." Tapi alhamdulillah, karena saya sudah pernah mengalami keajaiban-keajaiban sejak kenal MR saya maju aja, saya awali degan GT (Garpu Tala, red). Saya dapat surat Ali Imran: 75. Masyaallah....saya curhatnya Dinar dan saya dapatnya ayat Dinar jg. Maka semakin mantap hati saya untuk daftar. Dan saya daftar di last minute, itu jg karena dapat uang kaget untuk daftarnya.

Seiring waktu berjalan keajaiban-keajaiban itu mulai dirasakan. Di awal-awal adaptasi, di saat saya yang belum mahir degan aplikasi, Allah kirim tentaranya untuk bantu saya pesan barang dll. Sampai akhirnya saya bisa pesan sendiri.dan Alhamdulillah dapat costumer tetap dan akhirnya jadi PDKR saya.

Ada satu kejadian lain, dan saya merasa ini adalah ujian saya. Saat saya merasa punya pelanggan tetap dan PDKR baik yang loyal lagi punya modal besar, sekali pesan 10 Dinar. Saat itu pula peluang untuk jadi Wakil Resmi sesi berikutnya dibuka. Sempat terbersit di kepala saya, "kasih tau gak ya?". Satu sisi merasa takut kehilangan asset, karena jujur saya sudah "sayang" sama dia, tapi satu sisi lagi kok saya merasa menutup pintu rezeki orang.

Tapi alhamdulillah, saya gak biarkan pikiran yang gak baik itu berlama-lama di kepala saya. Saya lagsung kabari dia untuk meng-upgrade dirinya untukjadi WR. Dan saya bantu lalu bimbing sampe akhirnya beliau sah jd WR. Saya cuma berharap dan berdoa, semoga Allah beri ganti yang lebih baik lagi. Saya yakinkan hati ini, gak ada yang jamin kalau dia terus sama saya, dia akan jadi 
salah satu sumber rezeki saya. tapi kalau saya mudahkan dia untuk memperoleh rezeki baru lagi, pastinya Allah akan mudahkan saya juga.

Alhamdulillah, ajaib memang, sejak beliau jadi WR, pesanan demi pesanan masuk. Pernah satu hari saya keluar seharian. Yang awalnya cuma mau menuju satu tempat karena ada yang mau yadan bi yadin waktu itu ajaibnya, semua tempat yang saya singgahi closing.

Berawal dari saya cuma mau ngambil paket di pos satpam tempat saya kerja. Lalu terus lanjut ke customer tapi karena gak ingat bawa helm, saya mampir minjam helm teman ke kantor. 3 Dinar 1/4 dipinang saat itu. Lanjut perjalanan, mampir ke tempat teman numpang toilet, eh satu Dinar dipinang lagi sama temannya teman saya yang kebetulan datang bertamu di saat saya di tempat itu. Lalu lanjut nemanin teman tadi dulu ketemuan sama temannya lagi karena ada transaksi mereka. Qadarullah, 1/4 Dinar terpaksa saya lepaskan lagi plus daftar PDKR lgsung. seperti dihipnotis beliau mengeluarkan KTPnya minta dia dijadiin PDKR saya. Dia lagsung transfer di depan saya, plus transfer untuk 1/4 dinarnya. Masyaallah, padahal tujuan utama belum nyampe juga, dinar saya sudah berceceran di jalan. Lanjut ke tempat tujuan utama. Alhamdulillah, si ibu baru menjual emas Antamnya 20 juta dan beliau pesan 4 Dinar KR. Lanjut pulang, saya mampir lagi ke tempat teman tadi, mengembalikan helm yang saya pinjam, eh, 1/4 Dinar harus saya keluarkan lagi plus minat jadi PDKR. Masyaallah, sampe rumah saya nangis terharu. "Allahu Kariiim..Maka nikmat Allah mana lagi yang kau dustakan?’[22].

The statement above explains that many Dinar KR Official Representatives and Partners are interested in joining the Magnet Sustenance community. Even though they feel they have no previous capital, they still believe that there will be miracles as long as they hold on to the al-Qur'an, as has been taught in training by the Fortune Magnet community.

In some cases of this kind, the verses of the alQur'an used are not the same. Everyone has their verse obtained through the concept of a tuning fork. They believe the verses obtained by not tracing the interpretation of the verses, but only by seeing the meaning of the verses that can be caught at a glance after reading them. Then, they make the verse a handle and remembrance that continues to be read until the desire is achieved or the problem is solved. The concept of a tuning fork and a verse obtained by each person who practices it becomes the main attraction that distinguishes the KR Dinar from other Dinar or gold brands in Indonesia. It can be said that the KR Dinar is spread through a very subtle promotional way and with unlimited verses of the al-Qur'an.

When the Muamalah Market case broke out some time ago using Dinar coins, the central leadership emphasized that the KR Dinar was only a commodity, not a transaction tool. They stated that the KR Dinar followed the MUI fatwa regarding the Dinar as a commodity or jewelry and should not be treated as a substitute for Rupiah in Indonesia. Even in one of the writings of the founder of Dinar KR, an explanation was found that the owner of the Dinar KR only had to keep his Dinar until the end of time. Only Prophet Isa and Imam Mahdi can use the KR Dinar. Therefore, the KR Dinar is decorated with the engraving of the prayer of the Prophet Isa, which is at the end of the QS. AlMaidah: 114.

Besides being supported by the Magnet Sustenance community, Dinar KR also has a smaller and more specific community. Dinar KR social media is not explained in detail about the conditions for joining the Dinar KR Club. However, it is explained that Dinar KR Club members have a special form of $0 \%$ spread. It is an exciting feature because all gold brands in Indonesia have an average spread of over $16 \%$ [23].

\section{COMMODIFICATION OF THE QUR'AN AS BRAND MARKETING}

The marketing strategy of Dinar KR by offering Islamic gold coin designs can be said to be effective because the Dinar KR community has now expanded to various regions and even to neighboring countries. With the slogan 'we provide the best gold coin design', Dinar KR has succeeded in exploiting the spiritual market potential of Muslims, who are the majority population in Indonesia. The KR Dinar inserts various religious symbols in the form of verses from the alQur'an in every marketing process in such an attractive packaging.

In addition, Dinar KR also promotes smaller spreads when compared to other gold brands in Indonesia. Even the spread of Dinar KR can reach $0 \%$ of consumers join the Dinar KR Club. This strategy is increasingly attracting the interest of the Muslim population in Indonesia to become part of the KR Dinar community.

Another strategy used by the KR Dinar to attract the interest of the spiritual market in Indonesia is to emphasize that purchasing the KR Dinar is the same as the jihad of wealth. They instilled the belief that spreading the KR Dinar is the sunnah of the Prophet, and the money used is a treasure that is spent in the way of Allah.

Another essential point that Dinar KR offers is a pro-government attitude. During the Muamalah market riot some time ago, Dinar KR remained warm and 
emphasized that the Dinar produced was categorized as a commodity and not a transaction tool, according to the MUI fatwa. Even the founder of Dinar KR explained that the owner of this Dinar only had to keep his coins until the end of time, then presented them to Prophet Isa and Imam Mahdi. They believe that only Prophet Isa and Imam Mahdi can use the Dinar.

The term commodification of religion comes from commodity (object of trade). Then the commodification of religion is defined as commercializing religious symbols that were initially in the form of guidance into commodities that can be traded. In line with this definition, Kitiarsa explained that the commodification of religion turns religion, which was not originally a commodity, into goods that can be exchanged in the spiritual market. According to Kitiarsa, commodification occurs through two components, namely commodities and markets [26].

In this case, the commodity offered by the KR Dinar is a gold coin with a full engraving of the verses of the al-Qur'an. The verses used are not only found on every KR Dinar coin but can also be easily found on the official website and several KR Dinar platforms. If you pay attention, the verses used in the pamphlets of Dinar KR promotional materials on FaceBook and Instagram are in the form of motivational verses to improve morals and several prayers. There is also a verse about the observance of Islamic holidays.

However, something unusual was found in one of the product photos uploaded by an official Dinar KR. He uses the Qur'anic manuscripts as a base for product photos. In some literature on $a d a b$ towards the Qur'anic manuscripts, this act is not justified. Imām Nawāwī, in his book, states that tawassud or making manuscripts as a base is unlawful [27][28].

Other verses used on the website and Telegram are more detailed. Most of the verses are written accompanied by a story about the reception of people who use it with the concept of a tuning fork. It can be understood that these people are not looking for the meaning of the verses that are used intensely and deeply, but they only understand the meaning at a glance and then make remembrance until their hearts are calm and their dreams are achieved.

Members are taught that saving the KR Dinar brings blessings through the many verses in the KR Dinar community, especially on the KR Dinar coin. There were also several testimonials of the blessings that some people felt for saving the KR Dinar. This doctrine makes the KR Dinar a commodity offered more and more in demand for blessing.

Meanwhile, the spiritual market for the KR Dinar can be mapped into two parts. The first is the internal market, namely the Magnet Rezeki community, where the founder of Dinar KR started his career. In the end, people who initially only joined the Dinar KR community were also automatically drawn into the
Magnet Sustenance community. Some of the concepts that exist in the Magnet Sustenance Community are also taught to the Dinar KR community.

With the support of the Magnet Rezeki community, the KR Dinar market is guaranteed because members of this community have spread throughout Indonesia and even abroad. The members have already trusted the Magnet Rezeki Community, who is also the founder of Dinar KR, so they don't hesitate to join as Dinar KR partners.

By using several verses of the al-Qur'an in images distributed on websites, Instagram, Facebook, and Telegram, all components of Dinar KR promote commodities to attract anyone interested in entering a more private zone, namely the Whatsapp group. In this Whatsapp group, the large-scale market is narrowed down with various kinds of persuasion, mainly by using testimonials on the use of Al-Qur'an verses so that people who have entered the group are then interested and register themselves as Dinar KR partners, or at least buy Dinar KR coins.

In this case, the process of commodifying the Koran on the KR Dinar is carried out by the owner (founder) of the KR Dinar which is then distributed through the central administrators and Official Representatives and Partners of the KR Dinar. The commodification process is carried out by using verses of the al-Qur'an both in pieces of Dinar, promotional materials and by carrying out readings of the al-Qur'an together.

Furthermore, commodification can be said to be successful if the parties behind it benefit because commodification is closely related to capitalism or commercialization. In this case, the party behind the KR Dinar benefits from the high potential of the spiritual market in Indonesia. The number of Dinar KR enthusiasts shot up quickly, matching other existing Dinar brands.

\section{CONCLUSION}

As a new Dinar product in Indonesia, the KR Dinar has proven to be able to fight the negative stigma that has been directed at the Dinar coin since the muamalah market case broke out. The KR dinar did not become an opposition to the government and succeeded in subtly persuasion using Islamic values. So that the demand for it is increasing day by day, even the Dinar KR community has expanded to neighboring countries. By taking advantage of Muslims' very promising market potential in Indonesia, Dinar KR is here by offering a very Islamic gold coin design, filled with engravings of the verses of the al-Qur'an, both clearly and implicitly in symbols. In addition, the KR Dinar is also supported by a large community with several methods that use the al-Qur'an, especially the Tala Fork method. This causes the KR Dinar to freely practice the al-Qur'an's commodification to become a very profitable selling point for its products. In addition, 
Brand Marketing is also carried out with the doctrine of jihad treasures. Even today, all KR Dinar owners can do is save coins and pass them on to their children and grandchildren. They claim the KR Dinar is a special offering for Prophet Isa and Imam Mahdi.

\section{REFERENCES}

[1] V. Mantalean, "Zaim Saidi Ditahan Polisi dalam Kasus PasZaim Saidi Ditahan Polisi dalam Kasus Pasar Muamalah di Depok, Ini Sebabnya," Kompas, Depok, Feb. 09, 2021.

[2] "Warga Soal Pasar Muamalah: BertahunTahun, Tak Disembunyikan,” CNN Indonesia, 2021.

[3] A. Fawaid and N. Mardlatillah, "Bias Ideologis Tafsir Hizb al-Tahr," MAGHZA: Jurnal Ilmu Al-Qur'an dan Tafsir, vol. 5, no. 2, pp. 184-209, Dec. 2020, doi: 10.24090/maghza.v5i2.4243.

[4] Nasrullah, "Keunggulan Dinar Khoirur Rooziqiin," Dinar Khoirur Rooziqiin, 2020. https://dinarkr.com/service/ (accessed Feb. 02, 2022).

[5] Z. Masduqi, "Penggunaan Dinar-Dirham Dan Fulus: Upaya Menggali Tradisi Yang Hilang (Studi Kasus Di Wilayah Cirebon)," Holistik, vol. 13, no. 2, pp. 121-136, 2012.

[6] "Habib Muhammad Luthfi Sudah Memiliki Dinar KR,” Instagram, 2020.

[7] "Ustad Tengku Zulkarnain Sudah Memiliki Dinar KR,” Instagram, 2020.

[8] "Syekh Ali Jaber Sudah Memiliki Dinar KR,” Instagram, 2020.

[9] "Visi Misi Yayasan Magnet Rejeki," 2020. https://dinarkr.com/service/ (accessed Feb. 02, 2021).

[10] Emas Berlian Corporation, "100 DINAR KHOIRUR ROOZIQIN UNTUK MASYARAKAT! Bersama Ustadz Nasrullah," Youtube, 2020. Accessed: Feb. 02, 2021. [Online]. Available: https://www.youtube.com/watch?v=Vq2gLi5D6OU
[11] H. Agustiawan, Peluang Emas. 2021.

[12] "The Best Gold Coin Design," 2020. https://dinarkr.com/ (accessed Feb. 02, 2021).

[13] M. A. al-Shabuni, Shofwah Al-Tafasir Juz 3. Beirut: Dar al-Khotob al-Ilmiyah, 2014.

[14] I. Kathir, Tafsir Al-Qur'an Al-Adhim Juz IV. Beirut: Dar al-Khotob al-Ilmiyah, 2017.

[15] "Makna Desain Dinar Khoirur Rooziqiin," Instagram, 2020.

[16] U. Sulastri, "Tiga Kekuatan Datangnya Rezeki," Facebook, 2020.

[17] Nasrullah, "Ilmu Garpu Tala," Telegram, 2016.

[18] "SIAPKAN TABUNGAN ANAK UNTUK MASA DEPAN BUAH HATI ANDA," Telegram, 2021.

[19] "MENJAGA, MEMELIHARA DAN MEMPERTAHANKAN HARTA,” Telegram, 2021.

[20] "Lepaskan Perisai Rezekimu," Telegram, 2021.

[21] “Law of Projection,” Telegram.

[22] H. Ginting, "Rezeki Berdinar-Dinar," Telegram, 2020.

[23] "Spread Emas Di Indonesia," Telegram, 2021.

[24] B. S. Turner, The New Blackwell Companion to Social Theory. John Wiley \& Son, 2016.

[25] A. Z. al-Nawawi, Al-Tibyan Fii Adaabi Hamalat Al-Qur'an. Surabaya: al-Hidayah, 2019.

[26] F. Greg and S. White, Expressing Islam: Religious Life and Politics in Indonesia. 2008. 